\title{
Reliability of Theophylline Clearance in Determining Maintenance Intravenous Aminophylline Therapy
}

\author{
Geoffrey R. Grambau, MD, Cary E. Johnson, PharmD, Paul F. Conlon, PharmD, \\ and John G. Weg, MD
}

A lthough theophylline has long been the primary drug used for the management of reversible obstructive airway disease, current recommendations for determining theophylline dosage have not been dependable and, when applied to individual patients, have resulted in a wide range of serum theophylline concentrations (STC) and frequent adverse reactions. ${ }^{1-3}$

The objective of this study was to evaluate the clinical reliability of using theophylline clearance values to adjust the theophylline infusion rate to achieve a desired STC and to determine the minimum time required for administration of a continuous theophylline infusion in a given population of patients before obtaining a single STC for the clinically reliable calculation of theophylline clearance.

\section{METHODS}

Twelve patients admitted to The University of Michigan Hospitals with disease manifesting reversible obstructive airway disease requiring intravenous theophylline therapy were subjects in this study. Patients with liver disease (serum bilirubin $>3.0 \mathrm{mg} / \mathrm{dL}$ or SGOT $>100 \mathrm{U} / \mathrm{mL}$ ), renal insufficiency (serum creatinine $>2.0 \mathrm{mg} / \mathrm{dL}$ ), congestive heart failure, or pulmonary edema or who received interfering drugs within 72 hours of admission were excluded. Patients who had received regular or sustained-release oral theophylline preparations in the previous six or 12 hours, respectively, were also excluded. The age of

From the Departments of Internal Medicine (Drs. Grambau and Weg) and Pharmacy (Drs. Johnson and Conlon), The University of Michigan Hospitals and The College of Pharmacy (Drs. Johnson and Conlon), The University of Michigan, Ann Arbor, MI. Address for reprints: Geoffrey R. Grambau, MD, Associated Pulmonary Specialists, PC, Suite 358, Bronson Medical Center, 252 E Lovell, Kalamazoo, MI 49007. the patients ranged from 19 to 64 years and four were cigarette smokers. Informed consent was obtained from each patient, and the study protocol was approved by the Human Use Committee of the University of Michigan Medical School.

Each patient received theophylline (aminophylline USP, Searle Lot 3-714) by constant intravenous infusion with an IVAC-500 constant infusion pump. Medication records were reviewed to insure that the infusion was maintained at a constant rate. If patients were receiving other medications, these were kept constant during the study period. In each case, the initial infusion rate and loading dose of theophylline were determined by the primary physician, who was not required to follow the investigator's recommendations. Blood samples for determination of the STC were obtained by venipuncture at 6,12 , and 24 hours (STC-6, STC-12, STC-24) after the initiation of the continuous theophylline infusion. The STC obtained at 24 hours represented $83.5 \%$ to $93.75 \%$ of the steady-state STC in the nonsmoking patients and $93.75 \%$ to $100 \%$ of the steady-state STC in the patients who were smokers. ${ }^{4}$ The STC obtained at 24 hours was used to calculate the patient's theophylline clearance as follows:

$$
\mathrm{Cl}=\frac{\operatorname{Ro} \times \mathrm{c}}{\mathrm{C}^{\mathrm{ss}}}
$$

where $\mathrm{Cl}=$ theophylline clearance $(\mathrm{L} / \mathrm{kg} / \mathrm{hr})$; Ro = aminophylline infusion rate $(\mathrm{mg} / \mathrm{kg} / \mathrm{hr})$; $c=$ conversion factor: aminophylline contains approximately $80 \%$ anhydrous theophylline ${ }^{5}$; and $\mathrm{C}^{s s}=$ steady-state STC in $\mu \mathrm{g} / \mathrm{mL}$.

Based on the patient's calculated theophylline clearance, a new maintenance theophylline infusion rate $\left(R_{1}\right)$ was calculated to produce a change, as desired by the primary physician, using the following rearrangement of equation 1 : 
GRAMBAU, JOHNSON, CONLON, ET AL

TABLE I

Demographic Data on 12 Study Patients

\begin{tabular}{|c|c|c|c|c|c|c|c|}
\hline \multirow[b]{2}{*}{ Patient } & \multirow[b]{2}{*}{ Sex } & \multirow[b]{2}{*}{$\begin{array}{l}\text { Age } \\
\text { (yrs) }\end{array}$} & \multirow[b]{2}{*}{$\begin{array}{c}\text { Welght } \\
\text { (kg) }\end{array}$} & \multirow[b]{2}{*}{$\begin{array}{l}\text { Cigarette } \\
\text { Smoker }\end{array}$} & \multirow[b]{2}{*}{$\begin{array}{l}\text { Loading Dose* } \\
\text { (mg) }\end{array}$} & \multicolumn{2}{|c|}{ Maintenance Infusion Rate } \\
\hline & & & & & & $\begin{array}{c}\text { Initialt } \\
\text { (mg/hr) }\end{array}$ & $\begin{array}{l}\text { Adjusted } \\
\text { (mg/hr) }\end{array}$ \\
\hline $\begin{array}{c}1 \\
2 \\
3 \\
4 \\
5 \S \\
6 \\
7 \\
8 \\
9 \\
10 \\
11 \S \\
12\end{array}$ & $\begin{array}{l}\mathbf{F} \\
M \\
M \\
F \\
M \\
F \\
F \\
F \\
M \\
M \\
M \\
M\end{array}$ & $\begin{array}{l}22 \\
29 \\
63 \\
64 \\
19 \\
55 \\
54 \\
23 \\
61 \\
58 \\
60 \\
53\end{array}$ & $\begin{array}{r}35 \\
73 \\
100 \\
73 \\
75 \\
51 \\
53 \\
59 \\
65 \\
88 \\
56 \\
81\end{array}$ & $\begin{array}{l}\text { No } \\
\text { Yes } \\
\text { Yes } \\
\text { No } \\
\text { No } \\
\text { No } \\
\text { Yes } \\
\text { No } \\
\text { No } \\
\text { No } \\
\text { Yes } \\
\text { No }\end{array}$ & $\begin{array}{c}200 \\
420 \\
400 \\
\text { None } \\
400 \\
300 \\
400 \\
300 \\
250 \\
300 \\
100 \\
\text { None }\end{array}$ & $\begin{array}{l}33 \\
70 \\
67 \\
50 \\
33 \\
50 \\
67 \\
50 \\
42 \\
50 \\
17 \\
50\end{array}$ & $\begin{array}{r}38 \\
107 \\
50 \\
33 \\
21 \\
67 \\
83 \\
58 \\
63 \\
73 \\
42 \\
75\end{array}$ \\
\hline
\end{tabular}

- Loading dose of aminophylline.

tInitial aminophylline infusion rate.

$¥$ Adjusted aminophylline infusion rate based on the serum theophylline concentration measured at 24 hours.

§This patient by history was very sensitive to theophylline and therefore the initial dose was lowered.

$M=$ male; $F=$ female.

$$
\mathrm{R}_{1}=\frac{\mathrm{Cl} \times \mathrm{C}^{\mathrm{ss}} \text { desired }}{\mathrm{C}}
$$

The new infusion rate was immediately started, and the STC was measured 24 hours later (STC-48).

Each patient's theophylline clearance was also calculated based on the STC- 6 and STC-12, and the STC resulting from change in the theophylline infusion rate was estimated using a rearrangement of equation 1. The STC-48 and the estimated STC, based on the patient's calculated theophylline clearance using STC-6, STC-12, and STC-24, were analyzed using least-squares linear regression. The total time from initiation of the loading dose to the final STC-48 was between 48 and 60 hours for all patients in the study.

All STCs were determined by high-pressure cationexchange chromatography according to a modification of the method of Weinberger and Chidsay. ${ }^{6}$ The $95 \%$ confidence limits of this method are $\pm 1.0 \mu \mathrm{g} / \mathrm{mL}$ for STC between 10 and $20 \mu \mathrm{g} / \mathrm{mL}$.

\section{RESULTS}

Twelve adult patients were subjects in this study (Table I). The STC measured at 6, 12, and 24 hours after the initial theophylline infusion rate was started and the respective calculated theophylline clearance are presented in Table II. The estimated and measured STC-48 are also presented in Table II. The equations and correlation coefficients for the leastsquares linear regression line for the measured STC48 versus the estimated STC-48 based on the theophylline clearance calculated using the STC-6, STC12, and STC-24 are as follows: $y=13.91-0.0001 x$, $r=-.0003 ; y=0.75 x+2.58, r=.81 ;$ and $y=0.92 x$ $+0.98, r=.99$, respectively.

\section{DISCUSSION}

Theophylline clearance varies significantly between patients; this was also demonstrated in this study (Table II). For this reason, theophylline therapy must be individualized to maximize the therapeutic effect and to prevent toxicity. This study evaluated a reliable and clinically useful method to do this. Once $80 \%$ of steady state is achieved, theophylline clearance based on a single STC and a desired change in STC may be reliably calculated using equations 1 and 2, which can be combined to give:

$$
\frac{\text { Ro }}{C^{s s} \text { (measured) }}=\frac{R_{1}}{C^{s s}(\text { desired })}
$$

The desired $C^{s s}$ is chosen and $R_{1}$ is determined.

Although the accuracy of equation 3 improves as 
TABLE ॥

\begin{tabular}{|c|c|c|c|c|c|c|c|c|c|c|c|}
\hline \multicolumn{12}{|c|}{ Pharmacologic Data on 12 Study Patients } \\
\hline \multirow[b]{2}{*}{ Patient } & \multicolumn{3}{|c|}{ Measured STC* } & \multicolumn{3}{|c|}{$\begin{array}{c}\text { Theophylline Clearancet } \\
\text { (L/kg/hr) }\end{array}$} & \multicolumn{3}{|c|}{$\begin{array}{c}\begin{array}{c}\text { Estimated STCF } \\
(\mathrm{mg} / \mathrm{L})\end{array} \\
\end{array}$} & \multirow{2}{*}{$\begin{array}{l}\text { Measured STCS } \\
(\mathrm{mg} / \mathrm{L})\end{array}$} & \multirow{2}{*}{$\begin{array}{c}\text { Theophylline } \\
\text { Clearance\| } \\
\text { (L/kg/hr) }\end{array}$} \\
\hline & $6 \mathrm{hr}$ & $12 \mathrm{hr}$ & $24 \mathrm{hr}$ & $6 \mathrm{hr}$ & $12 \mathrm{hr}$ & $24 \mathrm{hr}$ & $6 \mathrm{hr}$ & $12 \mathrm{hr}$ & $24 \mathrm{hr}$ & & \\
\hline $\begin{array}{r}1 \\
2 \\
3 \\
4 \\
5 \\
6 \\
7 \\
8 \\
9 \\
10 \\
11 \\
12\end{array}$ & $\begin{array}{r}10.8 \\
9.7 \\
19.2 \\
18.6 \\
23.6 \\
9.4 \\
13.4 \\
\text { NA } \\
8.8 \\
\text { NA } \\
\text { NA } \\
\text { NA }\end{array}$ & $\begin{array}{r}13.7 \\
6.8 \\
23.5 \\
21.0 \\
21.3 \\
9.7 \\
13.5 \\
6.4 \\
9.4 \\
8.9 \\
2.4 \\
5.9\end{array}$ & $\begin{array}{r}17.5 \\
7.1 \\
20.9 \\
20.1 \\
27.8 \\
10.3 \\
12.3 \\
7.4 \\
6.8 \\
9.5 \\
3.1 \\
7.5\end{array}$ & $\begin{array}{c}0.069 \\
0.078 \\
0.028 \\
0.029 \\
0.015 \\
0.082 \\
0.075 \\
\text { NA } \\
0.058 \\
\text { NA } \\
\text { NA } \\
\text { NA }\end{array}$ & $\begin{array}{l}0.054 \\
0.111 \\
0.022 \\
0.026 \\
0.016 \\
0.080 \\
0.074 \\
0.105 \\
0.054 \\
0.050 \\
0.010 \\
0.083\end{array}$ & $\begin{array}{l}0.043 \\
0.107 \\
0.025 \\
0.027 \\
0.013 \\
0.075 \\
0.081 \\
0.090 \\
0.075 \\
0.047 \\
0.077 \\
0.065\end{array}$ & $\begin{array}{c}12.4 \\
14.8 \\
14.3 \\
12.3 \\
15.0 \\
12.6 \\
16.6 \\
\text { NA } \\
13.2 \\
\text { NA } \\
\text { NA } \\
\text { NA }\end{array}$ & $\begin{array}{r}15.8 \\
10.4 \\
17.5 \\
13.7 \\
13.6 \\
13.0 \\
16.7 \\
7.4 \\
14.1 \\
13.0 \\
5.9 \\
8.8\end{array}$ & $\begin{array}{r}20.1 \\
10.8 \\
15.6 \\
13.3 \\
17.7 \\
13.8 \\
15.2 \\
8.6 \\
10.2 \\
13.9 \\
7.7 \\
11.2\end{array}$ & $\begin{array}{r}20.6 \\
10.8 \\
16.1 \\
14.0 \\
18.0 \\
14.2 \\
15.9 \\
8.1 \\
10.2 \\
13.2 \\
7.8 \\
10.3\end{array}$ & $\begin{array}{l}0.042 \\
0.107 \\
0.024 \\
0.026 \\
0.012 \\
0.073 \\
0.078 \\
0.096 \\
0.075 \\
0.050 \\
0.076 \\
0.071\end{array}$ \\
\hline \multicolumn{12}{|c|}{$\begin{array}{l}\text { "Measured after initial aminophylline infusion rate was started. } \\
\text { tCalculated from the STC obtained at } 6,12, \text { and } 24 \text { hours. } \\
\text { tEstimated for the adjusted aminophylline infusion rate and the calculated theophylline clearance based on the STC measured at } 6,12, \text { and } 24 \text { hours. } \\
\text { SMeasured } 24 \text { hours after the initiation of the adjusted aminophylline infusion rate (STC-48). } \\
\text { //Calculated from the STC measured } 24 \text { hours after the initiation of the adjusted aminophylline infusion rate. } \\
\text { STC = serum theophylline concentration; NA = not available. }\end{array}$} \\
\hline
\end{tabular}

the STC approaches steady state, the ability to make theophylline dosage adjustments prior to steady state being achieved is of great clinical importance.

All patients in this study were successfully treated with theophylline, with their infusion rate adjusted to a predicted STC using the calculated theophylline clearance approximated from a single STC obtained 24 hours after the start of the theophylline infusion. Obtaining an STC prior to 24 hours of a continuous theophylline infusion is recommended in patients exhibiting signs or symptoms of theophylline toxicity or in patients who are not responding or have not received an initial loading dose of theophylline. Patients with congestive heart failure or hepatic disease and those receiving drugs known to increase theophylline half-life may have theophylline dosage adjustments overestimated by equation 3 unless the time for the initial STC is appropriately increased. The theophylline clearance prediction method of Chiou and co-workers, ${ }^{7}$ using two appropriately spaced STCs may be considered for use in these patient populations and has been evaluated. ${ }^{8}$ Although dose-dependent kinetics exist for theophylline, evidence for this was not apparent in this study since the STC changed in direct proportion to the dose and with predictability.

This study demonstrates the clinical reliability of using theophylline clearance to individualize the theophylline infusion rate to achieve a desired STC. It also shows that a single STC obtained at 24 hours for a given patient population is the most accurate for the calculation of theophylline clearance.

\section{REFERENCES}

1. Hendeles L, Bighley L, Richardson R, et al: Frequent toxicity from IV aminophylline infusions in critically ill patients. Drug Intell Clin Pharm 1977;11:12-18.

2. Mitenko PA, Ogilvie RI: Rational intravenous doses of theophylline. N Engl I Med 1973;289:600-603.

3. Weinberger MM, Matthey RA, Ginchansay EJ: Intravenous aminophylline dosage: Use of serum theophylline measurement for guidance. JAMA 1976;235:2110-2113.

4. Hendeles L, Weinberger M, Bighley L: Disposition of theophylline after a single intravenous infusion of aminophylline. Am Rev Respir Dis 1978;118:97-103.

5. Floyd RA, Bartlet LN: Percent theophylline in aminophylline. Drug Intell Clin Pharm 1978;12:177.

6. Weinberger MM, Chidsay C: Rapid analysis for theophylline in serum by use of high pressure cation exchange chromatography. Clin Chem 1975;21:834-837.

7. Chiou WL, Gadalla MAF, Peng GW: Method for the rapid estimation of the total body clearance and adjustment of dosage regimens in patients during a constant-rate intravenous infusion. I Pharmacokinet Biopharm 1978;6:135151.

8. Johnson MH, Burkle WS: Evaluation of the Chiou method for determining theophylline dosages. Clin Pharm 1984;3:174-178. 